\title{
Trends in Financial Management of Municipalities in Conditions of the Slovak Republic
}

\author{
Dana ORSZÁGHOVÁ ${ }^{1}$, Radomíra HORNYÁK GREGÁŇOVÁ ${ }^{1}$, Viera \\ PAPCUNOVÁ ${ }^{2}$ \\ ${ }^{1}$ Slovak University of Agriculture in Nitra, Nitra, Slovak Republic \\ \{dana. ors zaghova, radomira.greganova\} @uniag.sk \\ ${ }^{2}$ Constantine the Philosopher University in Nitra, Nitra, Slovak Republic \\ vpapcunova@ukf.sk
}

\begin{abstract}
Changes in the socio-economic conditions of countries initiate modifications in the management of its economic and social processes, which are also followed by conversions in the public administration. At the same time, they are also looking for the concepts of rational organization and effective management of the public administration. The public administration of the Slovak Republic is created by local self-government and regional selfgovernment. Municipalities represent the local self-government bodies. The effective conditions of the municipalities are creating the effective setting of its financing. Until 2004 the financing of municipalities was determined annually by the state budget act and for the municipalities distributed from the state budget a share of the tax of personal income, which consisted of three taxes: tax of personal income, tax of the corporation income and road tax. In 2005 the fiscal decentralization took place in Slovakia as a part of the consolidation of public finances, resulting in a new way of financing municipalities. The basis of the new financing system of municipalities was to determine the tax of personal income as a single share tax, in particular, because the dynamics of the income of this tax was expected to grow even in the medium term. The objective of the paper is to evaluate changes and trends in the financial management of municipalities based on selected fiscal indicators within the period $1993-2015$.
\end{abstract}

Keywords: Financial Management, Municipalities, Fiscal Decentralization, Polynomial Trends.

\section{Introduction}

Public organizations are confronted with an increasing number of problems, facing increased pressure how to efficient respond for complicated complex social, economic and political challenges [3]. The changes that took place in the public administration, especially since the 1970s in Europe, progressively brought the application of new governance principles for the public administration. This was accompanied by the more demanding conditions of economic development in the member states of the European Community. A well - functioning public sector is considered to be 
necessary for the economic and democratic performance of countries. Recent public sector reforms have been attempted in each countries to achieve a better performing public sector [18]. The public administration had to cope with the limited financial resources available to it from state budgets. The idea of building a local public administration on a self-governing basis was crucial in terms of strengthening the citizen's political status in the development of democracy [5]. The first democratic elections to the self-governing bodies, which took place on 23 and 24 November 1990 in Slovakia, created a new space and conditions for the restoration of civic activities and the development of local democracy. The Law No. 369/1990 Coll. about the municipal establishment defined self-governing functions of the municipality, which started to act as a legal person. Instead of the centralist principle and the top-level directives, it has begun to apply the principle of subsidiarity. Under this principle, it is necessary to manage public affairs and conduct them at the level closest to the tasks and the problem.

The period 1989-1990 was important for the local self - government in Slovakia and brought to municipalities greater opportunities to influence their socio-economic development of their area. Before 1989, in Slovakia there was applied the central model of public administration; in the current period it is a dual model. In practice this meant the establishment of self - governing bodies at the local level and then at the regional level. Municipalities as representatives of the local self - government bodies in the process of the reform of public administration received from 1990 to the present about 4,000 competencies that are required to perform in relation for the inhabitants. The first competencies were the registers that the municipalities and towns gained to competence in 2001. The following year, municipalities and towns gained to competences in the regional education. Municipalities started to use the possibility of entrusting the municipal property to managing administrators in the process of reform of public administration, because one of outcomes was the transfer competencies from the state administration to local self - government in the selected services [e.g. education, health, social affairs, etc.], which have a direct impact on the quality of life in towns and municipalities. The civic and technical facilities, including the availability of basic goods and services, are currently one of the basic functions of the municipalities [in addition to the function of residential, work, protection and environment, recreational, etc.] which determine the future direction and development of municipalities [2]. But technical progress is not only simply a matter of investing into the physical or human capital, but it is also determined by its institutional environment [13]. In general, technical innovations are expected to bring higher economic effects than non-technical ones [21].

The significant milestone in the development of financing of the municipalities in Slovak Republic was the fiscal decentralization. The fiscal function of taxes is very important all over the world [19]. Fiscal decentralization represent the process of assigning tax and spending competences to various levels of government to achieve their relative autonomy and self-sufficiency [20]. Since 2004 in Slovakia has been decentralized the tax system, thereby enhancing the competencies in tax collection and tax collection for towns and municipalities [12]. Fiscal decentralization in the world [14] is seen as strengthening self-government revenues through their power to 
determine the amount of taxes (in the form of local taxes or tax mark - up), while at the same time it is essential to ensure the territorial principle of these taxes (e.g. the self - government becomes the tax recipient where residents pay the tax).

Although, in the years 2002-2004 were handed into municipalities and higher territorial units important competences from the state and also the property, until since January 1, 2005, the system of financing of the local and regional self-government has fundamentally changed. Until December 31, 2004 have been paid to the municipal budget from the state yield from three taxes - tax of the personal income, corporate income tax and road tax. Corporate income tax currently represents the highest percentage of the total state budget incomes [4]. Since 1st January 2005 these three taxes replaced for one tax, namely the tax of personal income. The new municipal billing system as part of the reform of the public finance management will allow financial comparisons of public administration entities in the Slovak Republic with public administration entities that already use international standards.

\section{$2 \quad$ Material and Methods}

The main objective of the paper is to evaluate changes and trends in the financial management of municipalities based on selected fiscal indicators. We decided to analyze the time period $1993-2015$ and divided years in two main parts: $1^{\text {st }}$ period includes years 1993 - 2004 and $2^{\text {nd }}$ period consists of years 2005 - 2015. Years of the first period are before the fiscal decentralization, when the municipalities received revenues from three taxes from the state budget: the tax of personal income, corporation tax and road tax. The second period [years 2005 - 2015] is after the fiscal decentralization and a single share tax for municipalities became the tax of personal income.

Financing of the tasks of the local self - government is a combination of own incomes and transfers. Their ratio depends on the ratio of the original competencies and the transfer competences from the state administration [10]. Financing of original [self-government] tasks is mainly realized from own resources. The costs of the transfer competences from the state administration are fully repaid by the state. The municipalities, as separate economic and legal entities, have the opportunity to perform their tasks over the framework of their competences if they have the means and the necessary level of professional and active human potential [1]. Municipalities' own financial resources are primarily tax incomes, which are made up of two basic components - income from the share tax, which is made from the tax of the personal income and incomes from local taxes. Municipalities use the income from the tax of the personal income primarily to ensure the original competences and since the volume of funds from this tax is closely related to the development of the economy at the state level. We use selected indicators and evaluate the effects of changes of the economy in the Slovak Republic and their impact on the financing of municipalities. Via regression methods we express non-linear modeling functions which are applied for evaluation of the development of selected financial indicators. The obtained statistical data will be processed by computational and graphic tools of MS Excel. In 
graphs we modified the scale on the y-axis for better illustration. The figure for the observed particular data parameter contains the equation of the trend line and the determination index.

According to the shape of the modeling function $y=f(x)$, depending on parameter $x$, the regression functions can be divided into linear and nonlinear type. Frequently, a linear estimate function is used in data analysis. But there are a lot of cases where non-linear estimates are required. In our case the examination of trends is based on the non-linear estimates and functions created by tools of MS Excel known as "trend lines". In data modeling we apply polynomial trends with the most appropriate grade of a polynomial. Polynomial functions are based around the formula

$$
y=a x^{n}+b x^{n-1}+c x^{n-2}+\cdots+m,
$$

where dependent variable $y$ is expressed by independent variable $x, n$ means the grade of a polynomial function and $a, b, c, \ldots, m$ are coefficients of a polynomial.

The verification of the correctness of the created regression model results in the calculation of the numerical characteristics, which in an exact form describe the quality of the calculated models. We use a determination index to verify the accuracy of the estimated non-linear function. The determination index is used to explain the regression quality, how much the regression of the actually measured value registers. The determination index has the following mathematics expression:

$$
I_{Y X}^{2}=\frac{S_{M}}{S_{C}}=1-\frac{S_{R}}{S_{C}},
$$

where $S_{M}$ represents the theoretical sum of squares, $S_{C}$ is the total sum of squares and $S_{R}$ is the residual sum of squares. The determinations index can take values from 0 to 1. As the index value approaches 1 , the larger part of the total variability is explained by the model [ $y$ depends on $x$ ]. Conversely, if the determination index is close to 0 , the lesser the total variability is explained by the model. The determination index is often used as a criterion of the choice of a particular regression function.

\section{Results and Discussion}

Gross domestic product, unemployment, inflation etc. (as the basic macroeconomic indicators) are used to measuring and comparing the performance of national economies. Their development is determined by other macroeconomic indicators and they are significantly interlinked. Unlike gross domestic product, unemployment or inflation presents a social phenomenon which, in addition to many negative social consequences, causes economically quantifiable losses. [17]. In the assessment of development of GDP, it is possible to see an annual increase in the period 1993 2008, the economic crisis was reflected in Slovakia's conditions by slowing economic growth in 2009 (GDP decline in this year compared to the previous year was $6.52 \%$, which represents 4468.5 mil. $€$ ). Since 2010 GDP growth is increasing year on year (Fig.1). Year 1993 was the important time point of the recession in the Slovak 
economy due to changes in the transforming economy but also to the consequences resulting from the division of the former Czech-Slovak federation. The following years 1994-1995 were the years of economic recovery and macroeconomic stabilization of the country with relatively rapid economic growth, which was not linked to deepening macroeconomic imbalances.

The year 1996 represented continuing positive trends of the basic macroeconomic indicators (economic growth, inflation, unemployment). Despite the fact that 1997 and 1998 were characterized by an increase in the rate of inflation and an increase the pressures in the economy, in this period, economic growth was maintained mainly at the cost of a rapid growth in the debt of the Slovak economy and the deficit financing of public expenditures.

Developments in the main economic areas in 2000 indicated a tendency to improve the performance of the economy compared to 1999, which was mainly reflected in increasing the dynamics of GDP growth, favorable developments in inflation and improving developments in external economic relations. In the next two years, the growth of the Slovak economy continued to increase despite the slowdown in the global economy. The economic development in 2003 was marked by the preparation of major economic reforms and the implementation of several partial changes, particularly in the health and social system. Despite the light performance of the EU economy, Slovakia's economic growth remained at a comparable level with 2002. The main objective of the fiscal policy of the Government of the Slovak Republic in 2004 was to ensure that implementation of the budget in 2004 was another major step towards target the Maastricht criteria for joining the Euro area. The implementation of the Euro currency was the most important theme in Slovak country. At the end of the year 2007 , only $14 \%$ of Slovak companies were prepared in the terms of the Euro adaptation in information systems. Also in 2004 the positive macroeconomic development continued, which was supported by structural reforms in the area of public finances [6].

Any intervention of the government has its effects, whether intended or nonintended. The government may decide upon the optimal form and way of intervention if it is aware of the individual effects of the decision, e.g. financial, economic, political, legal, social or health-related, etc. [15]. The growth of the Slovak economy in 2005 again increased despite lightly recovery of the EU economy and reached the highest value since 1996. In 2005, could manifest direct or indirect repercussions of the reforms implemented in particular in 2003 and 2004. These are mainly the effects of the tax reform applied since January $1^{\text {st }}, 2004$ and then the pension reform applied from January $1^{\text {st }}, 2005$, social and labor market reforms public administration reforms with fiscal decentralization and public finance management reforms, which brought the introduction of severe budgetary constraints, the operation of the Treasury and the Agency for Debt and Liquidity Management. In 2006 Slovakia recorded the most dynamic growth among Central European countries. A similar scenario is repeated over the next two years. In 2009, as a result of the economic crisis, GDP fell by $4.7 \%$. This development reflects the impact of the economic crisis, which brought a significant weakening of foreign demand of our most important trading partners, which caused the declining dynamics of Slovak exports and industrial production, 
declining dynamics of the labor market and total domestic demand. The strong euro caused that Slovak exporters annually lost a few millions euros threated their employment and competitiveness [16]. As a result of the revival of the German economy, year 2010 marked a significant recovery in economic growth for the Slovak economy compared to the previous year. Economic growth continued in the next two years. In 2013 GDP growth slowed compared to the previous period. The change occurred in the following year, when GDP growth accelerated to $2.4 \%$. Higher growth was driven mainly by a recovery in domestic demand.

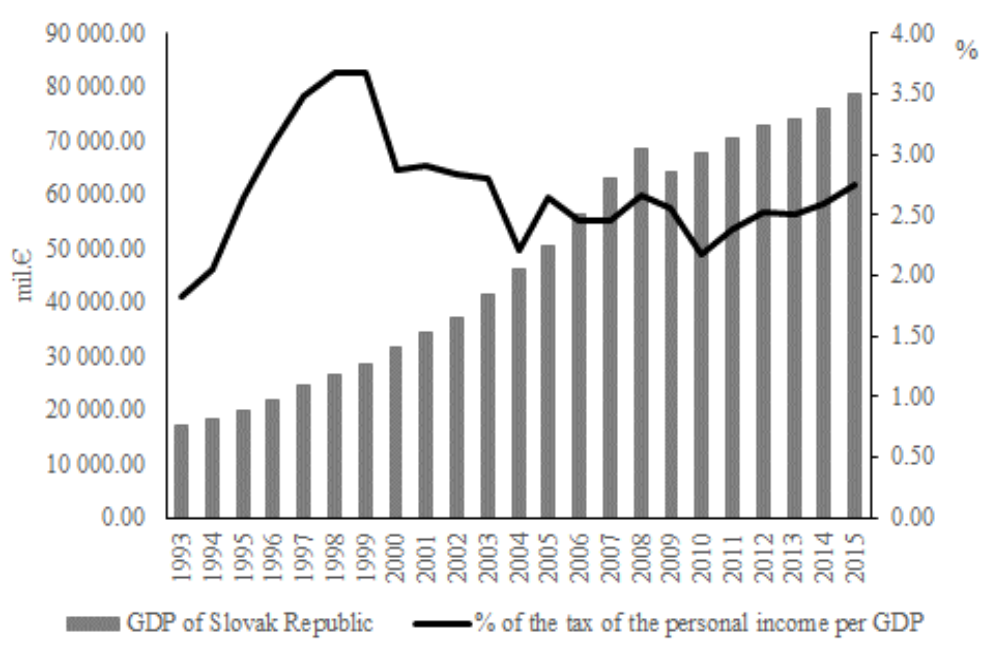

Fig. 1. Development of the GDP and the share of the tax of the personal income per GDP in the Slovak Republic in the period $1993-2015$.

The volume of selected funds received through the tax of the personal income changed during the monitored period. In the period 1993 - 1999, we recorded an annual increase in the total volume of this tax, which was also reflected in the annual increase of this tax of the share of GDP. The change occurred in 2000, when the yield from the tax of the personal income dropped by 142.6 mil. $€$, which is representing a decrease of $0.81 \%$ (Fig. 1). This decline was due to the adoption of Law No. 366/1999 Coll. about the income tax with effect from 1st January 2000, which reduced the tax of the personal income and tax of the corporate income (from $40 \%$ to 29\%). The reduction in the tax burden on both natural and legal persons was reflected in the reduction of the budgeted and also achieved revenues of these taxes. Over the next three years, it is possible to track the growth again of the tax of the personal income. The change occurred in 2004, when, following the amendment of Law No. 595/2003 Coll. [9] on income tax which replaced the law No. 366/1999 Coll. [7, 8], which brought a tax reform that substantially changed the tax system in the country and resulted in the transfer of the tax burden from direct taxes on indirect taxes and the introduction of a uniform $19 \%$ tax rate for both individual and legal persons. The introduction of a uniform tax rate also involved a change in the method of calculating 
non-taxable parts of the tax base. In 2005, compared with the previous year, the volume of funding from tax of the personal income increased, mainly as a result of wage base growth. The Ministry of Finance of the Slovak Republic states that in the same year the wage base grew to $11.2 \%$. In the next three years (2006, 2007 and 2008), the amount of funding received from the tax of the personal income increased each year. The above-mentioned annual growth was mainly driven by positive macroeconomic developments accompanied by a rise in the wage base. In 2008 to the introduction of a gradually decreasing non-taxable share of the taxpayer's base for 2007, which was fully demonstrated in the tax returns in 2008. Changes in the development of the tax of the personal income occurred in 2009 and 2010, when the tax of the personal income declined, in accordance with lowering household incomes due to the deterioration of macroeconomic developments caused by the global economic crisis. In 2011 the situation changed again; there was an increase income from the tax of the personal income due to the gradual improvement of macroeconomic developments. In spite of the revival of the world economy after the crisis, its impacts in the conditions of Slovakia came with a certain time delay, caused mainly by the economic orientation of the country. In 2012 labor market developments worsened and GDP growth slowed as compared to forecasts, resulting in a slight decline income from the tax of the personal income. In the period 2013 2015 it is possible to monitor the annual increase income of the tax of the personal income, which is the result of the growing economy of Slovakia. In the period of financial and economic crisis municipalities have only limited possibilities for autonomous control of the income amount by their own tax and financial policy. Even though, this method is intensively used by many municipalities.

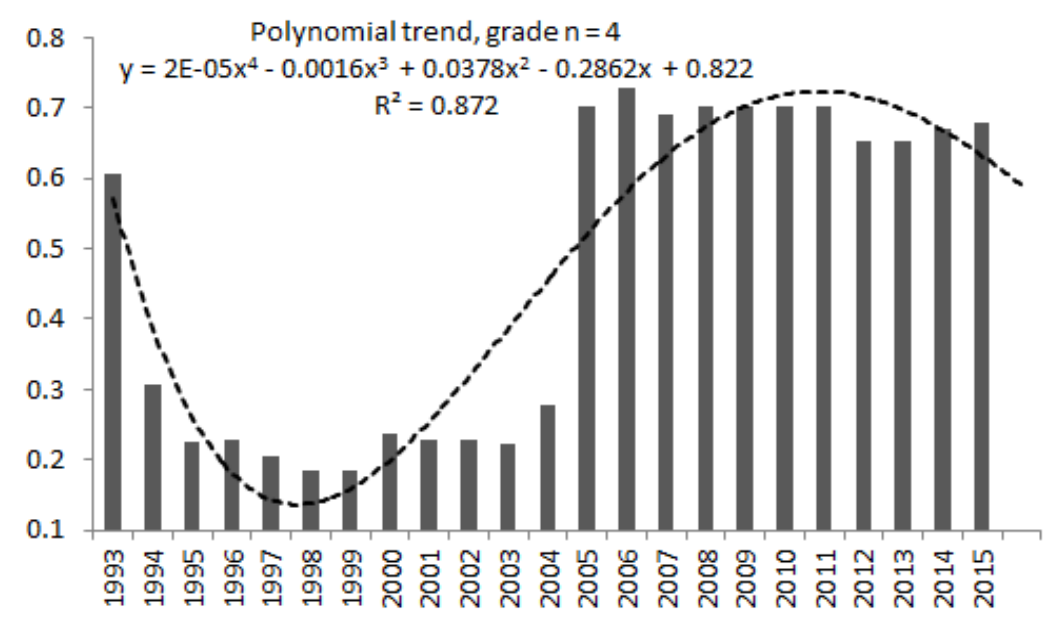

Fig. 2. Development of the Ratio indicator (municipal income from the tax of the personal income / yield of the tax of the personal income) in the period $1993-2015$.

Changes realized in the context of fiscal decentralization also reflect development of the Ratio indicator on the Fig. 2. The evolution of the coefficient can be divided into 
2 stages. The first stage consists of the years $1993-2004$, it means before fiscal decentralization and the second stage consists of years 2005 - 2015, after fiscal decentralization. The ratio indicator is modeled via the polynomial trend of the 4th degree, where the coefficient of determination is 0.872 (it expresses the suitability of the used trend model). Based on this, we can predict that there will be a decline the Ratio indicator in the coming period.

Financing of municipalities was determined annually from 2004 by the State Budget Act. Since 2005, about dividing income tax on personal income between municipalities is not decided the parliament, but the Government by the regulation. The positive aspect of this process was also the underflow of the municipalities, which to fear that they would receive less funding than before fiscal decentralization. Already in the first year municipal income from this tax increased more than three times compared to 2004. In this case, we can state that the choice of the tax of the personal income as a single share tax was correct. We can see an increase in income from this tax until 2008, which was also a result of the economic growth of the Slovak economy. Despite the fact that in 2009 the financial crisis took place and the total volume of selected funds from the tax of the personal income was reduced, there was no reduction of the coefficient in relation to municipalities. However, for the sustainability of the system, the Government has reduced the volume of funds distributed in the form of a share tax to municipalities in 2012. As a result of the improvement of the economic situation of Slovakia in 2014 and 2015, the coefficient was increased. The last change in the redistribution of the yield of the tax of the personal income occurred on January $1^{\text {st }}$, 2016, when $70 \%$ was reallocated to municipalities, $23.1 \%$ to HTU and $6.5 \%$ to the state.

From the analyses resulting, that the implemented fiscal decentralization brought on the one hand the increase of the financial autonomy of the municipalities and created a space for obtaining financial resources from own revenues. On the other hand, it contributed to the increase of the municipalities' dependence on the incomes from the state budget. While in 2005 the tax of the personal income made $34.8 \%$ of total municipal incomes and $57.2 \%$ of tax income, in the following year the tax of the personal income made more than $80 \%$ of tax income. This share is in the long run ranging from $70 \%$ to $80 \%$.

Despite the fact, that the state has distributed three types of taxes from the state budget to the municipalities because of fiscal decentralization, at that time the largest share was income from the tax of the personal income (in 1993 it was $94.55 \%$ ). Until 2005 , the share of the tax of the personal income had a fluctuating trend and a year before when realized the fiscal decentralization the share reached $42.89 \%$ (Fig. 3).

Since 2005, the share of the tax of the personal income has increased significantly on the tax incomes of municipalities. One of the reasons why realized the fiscal decentralization was also the increase of the municipal autonomy and the creation the space for obtaining financial resources from own incomes. However, fiscal decentralization on the one hand brought more funds to their budgets but, on the other hand, contributed to the increase of the municipalities' dependence on the incomes from the state budget. While in 2005 the incomes of municipalities from the tax of the 


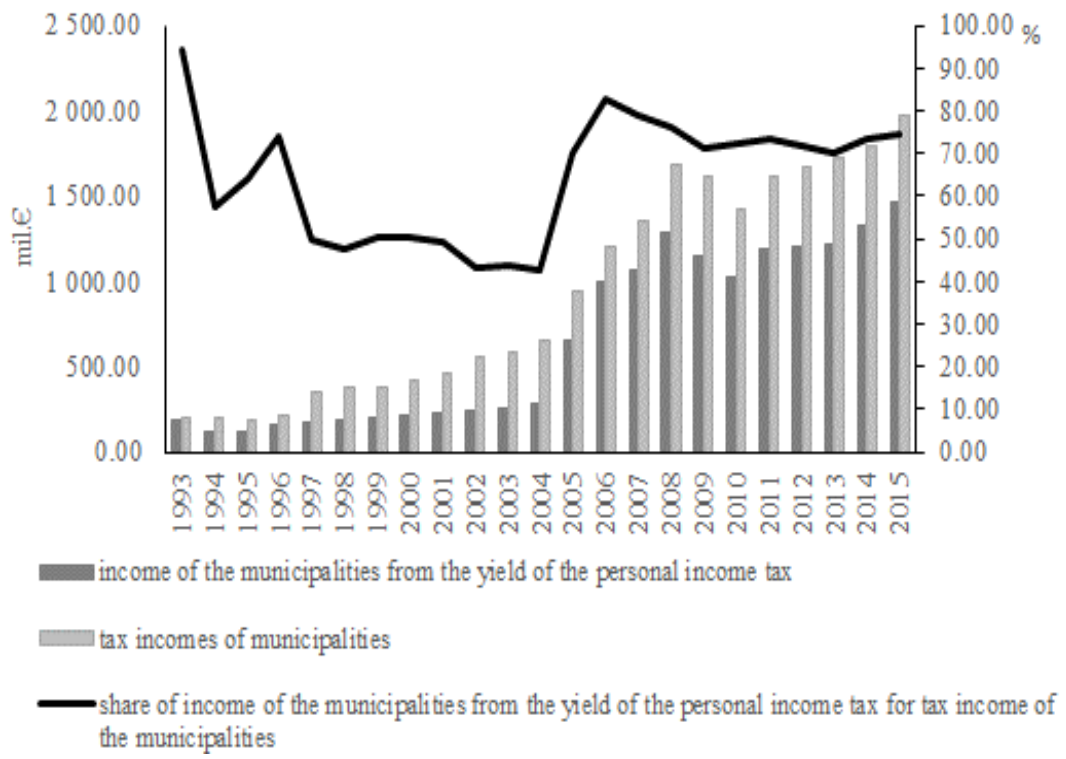

Fig. 3. Development of selected financial indicators of municipalities in the period $1993-$ 2015.

personal income constituted $69.98 \%$ of tax incomes of municipalities, in the following year the income from the tax of the personal income created on tax incomes of the municipalities $82.78 \%$. This high dependence of municipalities on the yield of the income from the tax of the personal income causes problems for municipalities when change the share of the tax of the personal income. Therefore, as a result of the implementation of consolidation measures, municipalities also require the state to return to $70.3 \%$ share of the tax of the personal income. However, the last adjustment of the coefficient valid since January $1^{\text {st }}, 2016$ has reached $70 \%$ share of the tax of the personal income for municipalities.

Taxes incomes of municipalities be creating by the share tax and the local taxes. The system of the local taxes also changed in the process of fiscal decentralization. Both these changes positively influenced the total amount of tax incomes, which increased 1.8 times in 2006 in comparison with the previous year. Taxes incomes of municipalities represent the significant share of total current income. The lowest share of tax incomes was in 1995 and 1996. The first extreme (local maximum) was recorded in 2001 (about 51\%) and then is followed by a significant decline. After 2005 , we see an increase of the share until for the next extreme (local maximum) in 2008 (about 61\%). In years 2009 - 2015 the development of indicators can be considered as balanced in the range $53-58 \%$ (Fig. 4). 


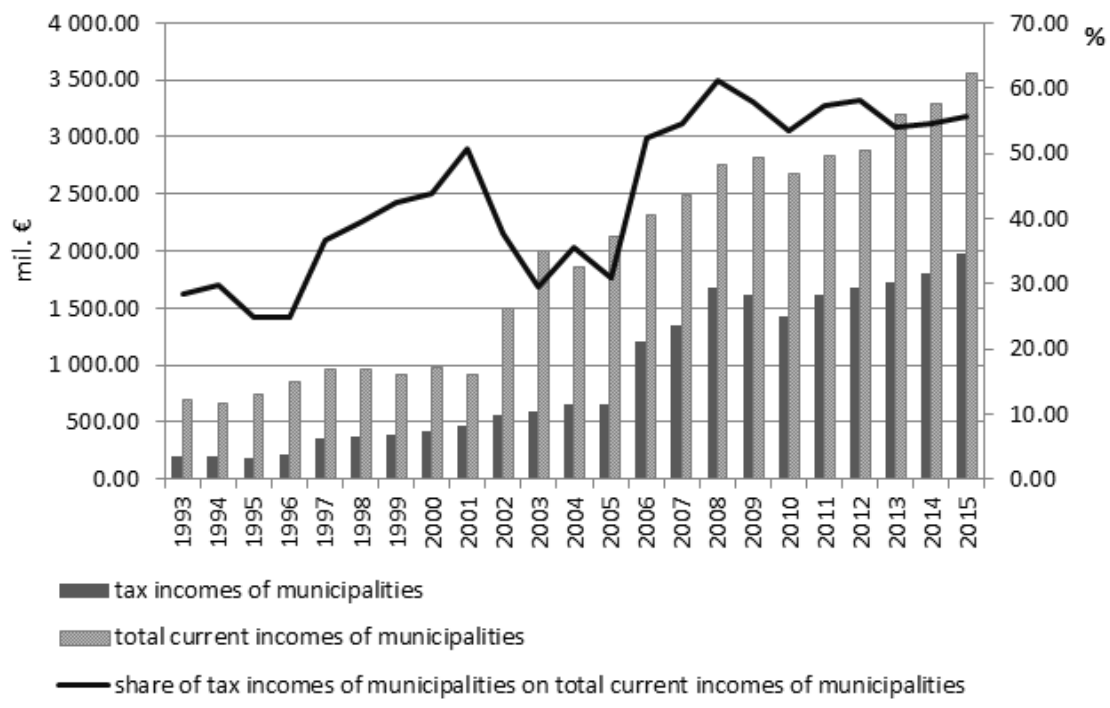

Fig. 4. Development of selected financial indicators of municipalities in the period $1993-$ 2015.

\section{Conclusion}

The basic objectives of the fiscal decentralization presented by the Ministry of Finance of the Slovak Republic [11] in the introduction of the fiscal decentralization into practice were: autonomy, accountability, justice and transparency. These four important phenomena should lead to the fulfillment of the essence of the fiscal decentralization, namely increasing the financial autonomy of municipalities. The principle of autonomy was that municipal authorities realized autonomous decisionmaking about using of their own incomes. This objective has been fulfilled because municipalities decide on the use of funds for their activities, except for purpose-bound financial resources that come from the state budget for the transferred state competences, respectively purpose-bound subsidies. Fair and responsible decisionmaking about the direction of public finances at the municipal level is in the hands of elected representatives of municipalities, who are not only involved in budgeting process but they also control the subsequent use of all funds, in order to ensure efficiency and also to improve the quality of life of inhabitants in the area.

The goal of transparency should be achieved through fiscal decentralization with the objective statistical indicators used to redistribute funds from the state budget. The set criteria for the calculation of the distribution of the share tax respects the competences of the self-government, taking into account their weights and the specifics of the individual territorial units (altitude, size of municipalities, presence of schools and school facilities in the municipality, etc.). However, the most important criterion for reallocation of this tax at municipal level is the number of inhabitants with permanent residence in the municipality, which suggests that municipalities can 
roughly predict the amount of the funds they receive in the form of the tax of the personal income. From this point of view, fiscal decentralization fulfilled its basic objectives because local self-government, through its elected representatives decides about the using of public funds independently, responsibly, fairly and transparently.

However, on the other hand, fiscal decentralization did not meet expectations in the area of financial autonomy of municipalities. The yield of the tax of the personal income share constituted $74.52 \%$ of the total tax income of the municipalities in 2015 and accounted for $41.46 \%$ of the total current incomes. As it is income that is closely linked to economic development, any negative developments at the macro level can cause a decline in yield, which negatively affects the overall financial performance of local self - governments. Such a negative example was also the economic crisis, which caused almost collapse in small municipalities, if the state did not help financially. It is therefore questionable whether the redistribution of only one tax on the part of the state represents the path to sustainable financial management, and whether it would not to be appropriate to consider other options which, in the event of adverse macroeconomic developments, would not have such a huge impact on the economies of municipalities. One of the options for a sustainable funding system is the idea of a mix of multiple taxes that emerged right in the years of the crisis.

The reform of the public administration in Slovakia has not been finished yet. At present in Slovakia the state administration reform is undergoing with the name ESO (Effective - Secure - Open State Government). Resulting of this reform will be restructuring, improvement and optimization of services provided by the state administration to inhabitants. Upon completion of the state administration reform, it is assumed that the reform will continue at the self-government. Since 2004, there has been a debate on municipal reform, which should result in the consolidation of the settlement structure of the municipalities. In the case if the consolidation of the settlement structure was realized, it would be probably followed by the change of the financing of local self-government.

\section{References}

1. Balážová, E. et al.: Právne, ekonomické, manažérske a environmentálne aspekty výkonu kompetencií obcami. 1st edn. Slovenská pol’nohospodárska univerzita, Nitra (2012).

2. Dušek, J.: Availability of Basic Goods and Services in Towns and Municipalities of the South Bohemian Region, In: Klímová, V., Žítek, V. (eds.) 19th International Colloquium on Regional Sciences. Conference Proceedings, pp. 546-555. Masarykova univerzita, Brno (2016).

3. Hinţea, C.E., Profiroiu, C.M., Ţiclău, T.C.: Strategic Planning and Public Management Reform: The Case of Romania. Transylvanian Review of Administrative Sciences (Special Issue), 30-44 (2015).

4. Hudáková, M., Andrejovská, A.: Classification of EU Countries in the Context of Corporate Income Tax. Acta Universitatis Agriculturae et Silviculturae Mendelianae Brunensis 64(5), 1699-1708 (2016), DOI: 10.11118/actaun201664051699.

5. Klus, M., Kováčová, E.: Verejná správa Slovenskej republiky a jej manažment od roku 1989. Acta Universitatis Sanctorum Cyrilli et Methodii Tyrnaviae Res Publica 2010(1), 11-32 (2010). 
6. Kučera, M., Fil'a, M., Látečková, A.: Information Systems in the Adaptation Process of the Euro Currency in Slovakia. Agricultural Economics, 54(8) 352-357 (2008).

7. Národná rada Slovenskej republiky: Law about the income tax, L. 366/1999.

8. Národná rada Slovenskej republiky: Law about municipality establishment, L. 369/1990.

9. Národná rada Slovenskej republiky: Law about the income tax, L. 595/2003.

10. Marišová, E. et al.: European Union public administration and development policies and variations in V-4 countries. 1st edn. Slovenská pol'nohospodárska univerzita, Nitra (2010).

11. Ministry of Finance of Slovak Republic: Fiskálna decentralizácia ako čast' reformy verejnej

správy, http://www.finance.gov.sk/Components/CategoryDocuments/s_LoadDocument.aspx?categ oryId=3513\&documentId=4130, last accessed 2017/05/15.

12. Petrášová, V., Beresecká J.: Creativity and Public Administration as Opportunity for Development of Regional Economy. In: Klímová, V., Žítek, V. (eds.) 15th International Colloquium on Regional Sciences, pp. 399-409. Masarykova univerzita, Brno (2012).

13. Qineti, A., Matejková, E., Pietriková, M., Serenčéš, R., Tóth, M., Dvořák, M.: Looking for the evidence of socio - economic convergence within the European Union. Agricultural Economics 57(8), 384-393 (2011).

14. Sedláková, S.: Fiškálna decentralizácia - jej význam a dôsledky pre územnú samosprávu. In: Šoltés, V. (eds.) National and Regional Economics VII, pp. 806-810, Technical University in Košice, Košice (2008).

15. Staroňová, K., Hejzlarová, E., Hondlíková, K.: Making Regulatory Impact Assessment Gender-Sensitive: The Case of the Czech Republic and Slovakia. Transylvanian Review of Administrative Sciences 51(E), 89-105 (2017), DOI: 10.24193/tras.51E.6.

16. Urbaníková, M.: Využitie finančných derivátov pri riadení vybraných druhov rizík. In: Čulík, M. (eds.) Financial Management of Businesses and Financial Institutions, vol. 7, pp. 1-8. VŠB-TU Ostrava, Ostrava (2009).

17. Vavrek, R., Jusková, M., Bednárová, L': Correlations between Selected Macroeconomic Indicators - Case Study of Slovak Republic and Czech Republic. In: Political Sciences, Law, Finance, Economics and Tourism, pp. 793-798, SGEM, Albena (2016).

18. Wynen, J.: Using Financial Management Techniqueswith in Public Sector Organizations, Does Result Control Matter? A Heterogeneous Choice Approach. Transylvanian Review of Administrative Sciences 2014(Special Issue), 202-222 (2014).

19. Zubr, V., Kolerová, K.: Changes in tax laws and the method of perception by citizens in the Czech Republic, In: Jedlička, P. (eds.) Hradec Economic Days 2013 vol. 3(1), pp. 539549, Gaudeamus, Hradec Králové (2013).

20. Žárska, E. et al.: Komunálna ekonomika a politika. 1st edn. Ekonóm, Bratislava (2007).

21. Žítek, V., Klímová, V., Králová, M.: Assessment of Regional Innovation Systems as an Assumption for Innovation Policy Adjustment. Transylvanian Review of Administrative Sciences 49(E), 169-186 (2016). 